\title{
STUDIA PHONETICA
}

A Canadian Series on Phonetics distributed throughout the world. From experimental phonetics to linguistic theory.

Already published

No. 1,1968 RECHERCHES SUR LA STRUCTURE PHONIQUE DU FRANCAIS CANADIEN

Pierre R. Léon 246 pages $\$ 6.50$

"The book... deserves serious consideration of all students of the French Language." (Modern Language Journal)

"... un ensemble d'études très intéressantes ... qui soulèvent toute une série de questions ... une importante contribution au dossier du français canadien." (Canadian Journal of Linguistics/Revue canadienne de linguistique)

No. 2, 1970 PROLEGOMENES A L'ETUDE DES STRUCTURES INTONATIVES

Pierre L6on \& Ph. Martin 244 pages $\$ 14.00$

". . an excellent exposition of the many theoretical and practical problems which confront researchers in this field.. a clear, comprehensive introduction to intonation studies which should be valuable to any reader interested in language." (French Review)

"... l'ouvrage d'initiation aux études d'intonation qui nous manquait - . aucun linguiste ne peut désormais ignorer ces indispensables 'prolégomènes'." (Le Français Moderne)

No. 3, 1970 PROSODIC FEATURE ANALYSIS/ANALYSE DES FAITS PROSODIQUES 230 pages $\$ 10.00$

"... number of world-known contributors to the field of prosodic analysis ... of high quality...

... marks a welcome progress in the development of our linguistic understanding of the prosodies." (French Review)

"Le point de vue d'éminents phonéticiens et linguistes sur un sujet épineux et fort controversé. Le statut des fonctions prosodiques en français et en anglais."

"... une brillante synthèse." (Le Français Moderne)

No. 4, 1971 ESSAIS DE PHONOSTYLISTIQUE

Pierre R. Lon 198 pages $\$ 7.00$

"This collection of brilliant Essais will be of interest to all those who would like to learn more about what brings the spoken language alive . . a valuable contribution to phonostylistics. (Canadian Modern Language Review)

". . . une incursion courageuse ... dans les champs de la paralinguistique et de la sémiotique.

... une théorie fonctionelle de la phonostylistique ... une claire mise au point. . . des pages savoureuses... un analyste aussi minutieux qu'amusé . . . des essais passionants et stimulants" (Le Français Moderne)

"Je recommande ces Essais savants et spirituels." (Les Nouvelles Littéraires)

No. 5, 1972 L'ACCENTUATION DES PRONOMS PERSONNELS EN FRANCAIS STANDARD

Monique Ĺon 150 pages $\$ 4.50$

"A short but excellent book ... a must for all teachers of French as a second language." CMLR

No. 6, 1972 LES POEMS DE RAYMOND QUENEAU, étude phonosłylistique

Rence Baligand 136 pages $\$ 4.00$

". . des pages remarquablement aérées et d'une lecture fort agréable, un tableau pratiquement exhaustif de tous les types de structures sonores utilisées par l'auteur." (French Revíew).

No. 7, 1973 PHONOLOGIE DE L'ACADIEN

Vincent Lucci 150 pages $\$ 8.00$

No. 8, 1973 INTERROGATION ET INTONATION

Allan Grundistrom et P. R. Léon (in press)

Forthcoming: La Mófaphore en phonótique 


\section{Our Contributors}

\section{Nos Collaborateurs}

Renée baligand is Assistant Professor of French at University College, University of Toronto.

Ronald c. beaumon't is Senior Instructor in the Department of German at the University of British Columbia.

J. K. chambers is Assistant Professor at the Centre for Linguistic Studies, and Co-ordinator of Undergraduate Linguistics, University of Toronto.

R. J. GREgG is Chairman of the Department of Linguistics, University of British Columbia and President of the Canadian Linguistic Association.

ERIC F. JAMES is Assistant Professor of French, Faculty of Education, University of Toronto.

nicole maury est Professeur Assistant à l'Université de Toronto, Départment de français.

H. REX WILson is Professor of English, University of Western Ontario. 